\title{
Corrigendum: Future global mortality from changes in air pollution attributable to climate change
}

Raquel A. Silva, J. Jason West, Jean-François Lamarque, Drew T. Shindell, William J. Collins, Greg Faluvegi, Gerd A. Folberth, Larry W. Horowitz, Tatsuya Nagashima, Vaishali Naik, Steven T. Rumbold, Kengo Sudo, Toshihiko Takemura, Daniel Bergmann, Philip Cameron-Smith, Ruth M. Doherty, Beatrice Josse, Ian A. MacKenzie, David S. Stevenson and Guang Zeng

Nature Climate Change 7, 647-651 (2017); published online 31 July 2017; corrected after print 16 October 2017.

In the version of this Letter originally published, the first row of Table 1, 'Base results', contained errors. These errors have been corrected in the online versions of this Letter. 